ISSN: 2302-8556

E-Jurnal Akuntansi Universitas Udayana

Vol.24.3.September (2018):1768-1798

DOI: https://doi.org/10.24843/EJA.2018.v24.i03.p05

\title{
Hubungan Kegunaan dan Kemudahan Penggunaan SAIBA dengan Kualitas Laporan Keuangan Kantor Wilayah DJP Bali
}

\author{
Budi Ismanto Prasetyo ${ }^{1}$ \\ I D.G. Dharma Suputra ${ }^{2}$ \\ ${ }^{1,2}$ Fakultas Ekonomi dan Bisnis Universitas Udayana, Bali, Indonesia \\ email: budiismantoprasetyo@gmail.com/085647369653 \\ Fakultas Ekonomi dan Bisnis Universitas Udayana, Bali, Indonesia
}

\begin{abstract}
ABSTRAK
Perubahan basis akuntansi dari kas menuju akrual (cash toward accrual) ke basis akrual disebabkan karena ada beberapa hal yang tidak bisa dipenuhi oleh akuntansi berbasis kas menuju akrual (cash toward accrual). Tujuan penelitian ini adalah untuk mengetahui dan menganalisis hubungan kegunaan dan kemudahan penggunaan Sistem Aplikasi Akuntansi Instansi Berbasis Akrual (SAIBA) dengan kualitas laporan keuangan Kantor Wilayah DJP Bali. Populasi dalam penelitian ini adalah para operator SAIBA dari seluruh satker di lingkungan Kantor Wilayah DJP Bali. Teknik pengambilan sampel yang digunakan adalah sensus. Teknik analisis data yang digunakan untuk menguji hipotesis dalam penelitian ini adalah analisis korelasi Spearman Rank. Hasil penelitian menunjukkan bahwa kekuatan hubungan dari variabel kegunaan SAIBA dengan kualitas laporan keuangan dapat digolongkan ke dalam tingkat hubungan sangat kuat, demikian pula kekuatan hubungan dari variabel kemudahan penggunaan SAIBA dengan kualitas laporan keuangan juga dapat digolongkan ke dalam tingkat hubungan sangat kuat.
\end{abstract}

Kata kunci: Kegunaan SAIBA, Kemudahan Penggunaan SAIBA, Kualitas Laporan Keuangan

\begin{abstract}
The change in the accounting basis from cash to accrual to accrual basis is due to some things that cash-accrual accounting can not meet. The purpose of this research is to know and analyze the relationship of usability and ease of use of Accounting System of Institution Based Accrual (SAIBA) with quality of financial report of Regional Office of DGT Bali. The population in this study are SAIBA operators from all work unit in DGT Bali Regional Office. The sampling technique used was the census. Data analysis techniques used to test the hypothesis in this study is Spearman Rank correlation analysis. The results show that the strength of the relationship of the SAIBA usability variable with the quality of the financial statements can be classified into very strong relationships, as well as the strength of the relationship of the SAIBA ease-of-use variable with the quality of the financial statements.
\end{abstract}

Keywords: Uses SAIBA, Ease of Use SAIBA, Quality of Financial Statement 
ISSN: 2302-8556

E-Jurnal Akuntansi Universitas Udayana Vol.24.3.September (2018):1768-1798

\section{PENDAHULUAN}

Undang-Undang Nomor 17 Tahun 2013 tentang Keuangan Negara mengamanatkan bahwa bentuk dan isi laporan pertanggungjawaban pelaksanaan APBN/APBD disusun dan disajikan sesuai dengan standar akuntansi pemerintahan. Standar akuntansi pemerintahan tersebut disusun oleh suatu komite standar yang independen dan ditetapkan dengan Peraturan Pemerintah setelah terlebih dahulu mendapat pertimbangan dari Badan Pemeriksa Keuangan.

Peraturan Pemerintah Nomor 71 Tahun 2010 tentang Standar Akuntansi Pemerintah merupakan dasar bagi pemerintah untuk menyusun laporan keuangannya. Menurut Pasal 4 peraturan pemerintah ini, pemerintah menerapkan SAP berbasis akrual. SAP berbasis akrual tersebut dinyatakan dalam bentuk PSAP dan dilengkapi dengan Kerangka Konseptual Akuntansi Pemerintahan. Kemudian pada Pasal 7 peraturan pemerintah ini dijelaskan bahwa Penerapan SAP Berbasis Akrual sebagaimana dimaksud dalam Pasal 4 ayat (1) dapat dilaksanakan secara bertahap dari penerapan SAP Berbasis Kas Menuju Akrual menjadi penerapan SAP Berbasis Akrual.

Dampak positif dari penerapan akuntansi pemerintahan berbasis akrual telah banyak diakui oleh para peneliti. Seperti kajian yang dilakukan oleh Deloitte (2004), yang menyebutkan bahwa akuntansi pemerintahan akrual secara signifikan memberikan kontribusi dalam meningkatkan kualitas pengambilan keputusan untuk efisiensi dan efektivitas pengeluaran publik melalui informasi keuangan yang akurat dan transparan, serta meningkatkan alokasi sumber daya dengan menginformasikan 
besarnya biaya yang ditimbulkan dari suatu kebijakan dan transparansi dari keberhasilan suatu program. Laporan keuangan yang dihasilkan dari penerapan basis akrual dimaksudkan untuk memberikan informasi yang lebih komprehensif dan lebih baik bagi para pemangku kepentingan baik para pengguna laporan keuangan dibandingkan dengan basis kas menuju akrual yang selama ini dianut. Hal ini sejalan dengan salah satu prinsip akuntansi yaitu pengungkapan paripurna atau full disclosure (Modul Proses Bisnis SAIBA). Karakteristik kualitatif laporan keuangan pemerintah sesuai Kerangka Konseptual Akuntansi Pemerintah (Peraturan Pemerintah Nomor 71 Tahun 2010) antara lain: (1) relevan, (2) andal, (3) dapat dibandingkan, dan (4) dapat dipahami.

Sistem akuntansi yang digunakan untuk menghasilkan laporan keuangan berbasis kas menuju akrual (cash toward accrual) digunakan sampai dengan tahun anggaran 2014. Mulai tahun 2015 basis akrual diterapkan pada Pemerintah Pusat untuk menghasilkan laporan keuangan. Kementerian Keuangan mengembangkan aplikasi akuntansi yang selama ini telah digunakan dalam basis kas menuju akrual (cash toward accrual) yaitu Sistem Akuntansi Instansi (SAl) menjadi Sistem Akuntansi Instansi Berbasis Akrual (SAIBA) untuk digunakan setiap Kementerian Negara/Lembaga. Sistem ini diterapkan secara paralel dengan implementasi sistem aplikasi keuangan terintegrasi sesuai dengan pentahapannya (Modul Proses Bisnis SAIBA).

Petunjuk teknis penerapan SAP berbasis akrual ini kemudian dituangkan dalam Peraturan Menteri Keuangan Nomor 270/PMK.05/2014 tentang Penerapan 
ISSN: 2302-8556

E-Jurnal Akuntansi Universitas Udayana Vol.24.3.September (2018):1768-1798

Standar Akuntansi Pemerintahan Berbasis Akrual pada Pemerintah Pusat. Pasal 2 PMK ini menyebutkan bahwa Pemerintah Pusat menerapkan SAP Berbasis Akrual mulai tahun 2015. Penerapan SAP Berbasis Akrual sebagaimana dimaksud dalam Pasal 2 dilaksanakan menggunakan Sistem Aplikasi Terintegrasi. Namun sampai dengan tahun anggaran 2015 berjalan, penggunaan Sistem Aplikasi Terintegrasi ini belum dapat dilaksanakan sehingga laporan keuangan berbasis akrual disusun menggunakan Sistem Aplikasi Akuntansi Instansi Berbasis Akrual (SAIBA) sesuai dengan Pasal 5 PMK ini. Penyusunan laporan keuangan berbasis akrual menggunakan SAIBA mengacu pada Modul Proses Bisnis SAIBA sebagaimana tercantum dalam lampiran PMK tersebut.

Perubahan basis akuntansi dari kas menuju akrual (cash toward accrual) ke basis akrual disebabkan karena ada beberapa hal yang tidak bisa dipenuhi oleh akuntansi berbasis kas menuju akrual (cash toward accrual). Laporan keuangan berbasis kas menuju akrual (cash toward accrual) belum memperlihatkan kinerja pemerintah secara keseluruhan, tidak menyajikan informasi keuangan yang sesungguhnya, dan kurang memberikan rekam jejak atas perubahan nilai ekuitas pemerintah (Amriani 2014).

Mulai tahun 2015 Pemerintah mengimplementasikan akuntansi berbasis akrual sesuai dengan amanat PP No. 71 Tahun 2010 tentang Standar Akuntansi Pemerintahan. Implementasi tersebut memberikan pengaruh pada beberapa hal dalam penyajian laporan keuangan. Pertama, Pos-pos ekuitas dana pada neraca per 31 Desember 2014 yang berbasis cash toward accrual direklasifikasi menjadi ekuitas 
Budi Ismanto Prasetyo dan I.D.G. Dharma Suputra. Hubungan...

sesuai dengan akuntansi berbasis akrual. Kedua, keterbandingan penyajian akun-akun tahun berjalan dengan tahun sebelumnya dalam Laporan Operasional dan Laporan Perubahan Ekuitas tidak dapat dipenuhi. Hal ini diakibatkan oleh penyusunan dan penyajian akuntansi berbasis akrual pertama kali mulai dilaksanakan tahun 2015 .

Perubahan aplikasi yang digunakan oleh satuan kerja pemerintah dari yang sebelumnya menggunakan aplikasi Sistem Akuntansi Kuasa Pengguna Anggaran (SAKPA) yang memakai basis cash toward accrual menjadi Sistem Aplikasi Akuntansi Instansi Berbasis Akrual (SAIBA) yang memakai basis Akrual, akan membutuhkan penyesuaian dari para operatornya untuk bisa menyajikan laporan keuangan sesuai standar yang berlaku.

Technology Acceptance Model (TAM) yang dikembangkan Davis (1989) menyatakan bahwa faktor yang mempengaruhi penerimaan suatu sistem adalah kegunaan persepsian (perceived usefulness) dan kemudahan penggunaan persepsian (perceived ease of use). Kegunaan persepsian teknologi informasi dapat diketahui dari kepercayaan pengguna TI bahwa penggunaan TI tersebut memberikan kontribusi positif bagi penggunanya (Nasution, 2004). Abas (2015) menduga bahwa penggunaan teknologi informasi berpengaruh terhadap kualitas laporan keuangan. Berdasarkan hal tersebut peneliti merumuskan hipotesis sebagai berikut:

$\mathrm{H}_{1}$ : Ada hubungan yang signifikan antara kegunaan Sistem Aplikasi Akuntansi Instansi Berbasis Akrual (SAIBA) dengan kualitas laporan keuangan Kantor Wilayah DJP Bali. 
ISSN: 2302-8556

E-Jurnal Akuntansi Universitas Udayana Vol.24.3.September (2018):1768-1798

Menurut Davis (1989) dalam TAM, reaksi dan persepsi pengguna TI akan mempengaruhi sikapnya dalam penerimaan penggunaan TI. Faktor yang mempengaruhi sikap pengguna adalah persepsi pengguna dan kemudahan penggunaan persepsian (perceived ease of use). Jika perusahaan tidak memiliki SIA yang baik, maka perusahaan tidak akan mampu menyediakan informasi yang memenuhi syarat kualitatif informasi untuk para pembuat keputusan (McLeod dan Schell, 2001). Pemerintah Pusat sebagai penyaji laporan keuangan juga telah merancang aplikasi SAIBA yang memungkinkan penyusun laporan keuangan menyelesaikan LKKL berbasis akrual dengan lebih mudah dan cepat serta meningkatkan tingkat akurasi data dan ketepatan informasi yang disajikan. Kemajuan teknologi informasi yang pesat serta potensi pemanfaatan secara luas maka dapat membuka peluang bagi berbagai pihak untuk mengakses, mengelola dan mendayagunakan informasi keuangan secara tepat dan akurat (Asterini, 2015). Berdasarkan hal tersebut peneliti merumuskan hipotesis sebagai berikut:

$\mathrm{H}_{2}$ : Ada hubungan yang signifikan antara kemudahan penggunaan Sistem Aplikasi Akuntansi Instansi Berbasis Akrual (SAIBA) dengan kualitas laporan keuangan Kantor Wilayah DJP Bali.

\section{METODE PENELITIAN}

Pendekatan yang digunakan dalam penelitian ini adalah pendekatan kuantitatif yang berbentuk korelasional yaitu penelitian yang bertujuan untuk mengetahui hubungan suatu variabel dengan variabel lainnya (Syaodih,2007:56). Penelitian ini dilaksanakan di Kantor Wilayah DJP Bali, yang berkedudukan di Gedung Keuangan Negara II, 
Jalan Kapten Tantular Nomor 4 Renon, Denpasar. Alasan kenapa memilih Kantor Wilayah DJP Bali karena kantor ini merupakan Unit Akuntansi Pembantu Pengguna Anggaran Wilayah, yang membawahi 13 satuan kerja. Obyek penelitian adalah suatu sifat dari obyek yang ditetapkan oleh peneliti untuk dipelajari dan kemudian memperoleh kesimpulan (Sugiyono, 2013:38). Obyek dalam penelitian ini adalah Sistem Aplikasi Akuntansi Instansi Berbasis Akrual (SAIBA) dan laporan keuangan Kantor Wilayah DJP Bali.

Variabel bebas adalah variabel yang mempengaruhi atau yang menjadi sebab perubahannya atau timbulnya variabel dependen atau terikat (Sugiyono, 2013:59). Dalam penelitian ini yang menjadi variabel bebas adalah Kegunaan SAIBA $\left(\mathrm{X}_{1}\right)$ dan Kemudahan Penggunaan SAIBA $\left(\mathrm{X}_{2}\right)$. Kegunaan SAIBA diukur menggunakan dimensi dalam Technology Acceptance Model (TAM) yaitu kegunaan persepsian (perceived usefulness). Kegunaan persepsian (perceived usefulness) didefinisikan sebagai sejauh mana seseorang percaya bahwa menggunakan suatu teknologi akan meningkatkan kinerja pekerjaannya. Kemudahan penggunaan SAIBA diukur menggunakan dimensi dalam Technology Acceptance Model (TAM) yaitu kemudahan penggunaan persepsian (perceived ease of use). Kemudahan penggunaan persepsian (perceived ease of use) didefinisikan sebagai sejauh mana seseorang percaya bahwa menggunakan suatu teknologi akan bebas dari usaha.

Variabel terikat adalah variabel yang dipengaruhi atau yang menjadi akibat, karena adanya variabel bebas (Sugiyono, 2013:59). Dalam penelitian ini yang menjadi variabel terikat adalah laporan keuangan Kantor Wilayah DJP Bali. Kualitas 
ISSN: 2302-8556

E-Jurnal Akuntansi Universitas Udayana Vol.24.3.September (2018):1768-1798

laporan keuangan Kantor Wilayah DJP Bali diukur menggunakan karakteristik kualitatif laporan keuangan sesuai dengan Peraturan Pemerintah Nomor 71 Tahun 2010 yaitu relevan, andal, dapat dibandingkan, dan dapat dipahami. Karakteristik kualitatif laporan keuangan adalah ukuran-ukuran normatif yang perlu diwujudkan dalam informasi akuntansi sehingga dapat memenuhi tujuannya (Lampiran I Peraturan Pemerintah Nomor 71 Tahun 2010).

Berdasarkan sifatnya, jenis data yang digunakan dalam penelitian ini adalah data kuantitatif. Data kuantitatif yaitu data yang berupa angka-angka atau data kualitatif yang diangkakan (Sugiyono, 2010:14). Data kuantitatif yang digunakan dalam penelitian ini adalah jawaban dari pertanyaan-pertanyaan kuesioner yang telah dikuantitatifkan.

Berdasarkan sumbernya, data yang digunakan dalam penelitian ini adalah data primer, yaitu data yang diperoleh langsung dari sumbernya, diamati, dan dicatat untuk pertama kalinya (Marzuki, 2000:55). Data primer dalam penelitian ini adalah hasil pengisian kuesioner oleh responden seputar variabel yang dimaksud.

Populasi adalah wilayah generalisasi yang terdiri dari atas Obyek atau subjek yang mempunyai kualitas dan karakteristik tertentu yang ditetapkan oleh peneliti untuk dipelajari (Sugiyono, 2013:115). Populasi dalam penelitian ini adalah operator SAIBA pada masing-masing satuan kerja di lingkungan Kantor Wilayah DJP Bali sebanyak 13 orang.

Sampel adalah bagian dari jumlah dan karakteristik yang dimiliki populasi tersebut (Sugiyono, 2013:116). Metode penentuan sampel yang digunakan dalam 
penelitian ini adalah metode sampling jenuh. Menurut Sugiyono (2014 : 85), sampling jenuh adalah teknik penentuan sampel bila semua anggota populasi digunakan sebagai sampel. Hal ini sering digunakan bila jumlah populasi relatif kecil, kurang dari 30 orang, atau penelitian yang ingin membuat generalisasi dengan kesalahan yang sangat kecil. Istilah lain sampel jenuh adalah sensus, dimana semua anggota populasi dijadikan sampel. Sampel dalam penelitian ini sebanyak 13 orang operator SAIBA dari seluruh satker di lingkungan Kantor Wilayah DJP Bali.

Responden dalam penelitian ini adalah operator SAIBA seluruh satuan kerja di lingkungan Kantor Wilayah DJP Bali. Responden dalam penelitian ini ditentukan dengan teknik sensus, yaitu seluruh operator SAIBA tersebut dijadikan responden penelitian. Jumlah operator SAIBA yang menjadi responden dalam penelitian ini adalah 13 orang dari 13 satuan kerja.

Teknik analisis data yang digunakan dalam penelitian ini adalah dengan uji korelasi Spearman Rank. Korelasi Spearman Rank digunakan mencari hubungan atau untuk menguji signifikansi hipotesis asosiatif bila masing-masing variabel yang dihubungkan berbentuk ordinal, dan sumber data antar variabel tidak harus sama (Sugiyono, 2012).

Rumus yang digunakan : $\rho=1-\frac{6 \sum d_{i}^{2}}{n\left(n^{2}-1\right)}$

Dimana:

$\rho=$ koefisien korelasi Spearman

$\mathrm{d}=$ perbedaan skor antar 2 variabel

$\mathrm{n}=$ jumlah sampel 
ISSN: 2302-8556

E-Jurnal Akuntansi Universitas Udayana

Vol.24.3.September (2018):1768-1798

\section{HASIL DAN PEMBAHASAN}

Statistik deskriptif merupakan statistik yang digunakan untuk menganalisa data dengan cara mendeskripsikan atau menggambarkan data yang telah terkumpul (Sugiyono, 2013:206). Pada sub bab ini peneliti akan menjabarkan hasil penyebaran kuesioner berkaitan dengan kegunaan dan kemudahan penggunaan Sistem Aplikasi Akuntansi Instansi Berbasis Akrual (SAIBA) dan kualitas laporan keuangan. Penilaian akan disajikan ke dalam nilai mean, frekuensi dan persentase. Persentase ini akan dibagi menjadi 2 (dua) bagian yaitu tanggapan positif (sangat setuju dan setuju) dan tanggapan negatif (netral, tidak setuju, dan sangat tidak setuju).

Tabel 1.

Distribusi Frekuensi Tanggapan Responden tentang SAIBA Membuat Anda dapat Bekerja Lebih Cepat

\begin{tabular}{lccccc}
\hline \multicolumn{1}{c}{ Tanggapan } & Skala & Frekuensi & Persentase (\%) & Skor \\
\hline Sangat Setuju (SS) & 5 & 5 & 38,46 & 92,31 & 25 \\
Setuju (S) & 4 & 7 & 53,85 & & 28 \\
Netral (N) & 3 & 1 & 7,69 & 7,69 & 0 \\
Tidak Setuju (TS) & 2 & 0 & 0,00 & 0 \\
Sangat Tidak Setuju (STS) & 1 & 0 & 0,00 & & 0 \\
\multicolumn{1}{c}{ Jumlah } & 13 & $100,00 \quad 100,00$ & 56 \\
\multicolumn{1}{c}{ Rata-rata/Kriteria } & 4,31 & \multicolumn{5}{c}{ Sangat baik } \\
\hline
\end{tabular}

Sumber : Hasil Pengolahan Data, 2017

Berdasarkan tabel 1 mengenai pernyataan SAIBA membuat Anda dapat bekerja lebih cepat mayoritas menjawab sangat setuju dan setuju sebanyak 12 orang dengan persentase $92,31 \%$. Selain itu responden menjawab netral sebanyak 1 orang dengan persentase 7,69\%. Secara keseluruhan mengindikasikan bahwa SAIBA mampu membuat responden bekerja lebih cepat.

Tabel 2.

Distribusi Frekuensi Tanggapan Responden tentang SAIBA dapat Meningkatkan Kinerja Anda 


\begin{tabular}{lccccc}
\hline \multicolumn{1}{c}{ Tanggapan } & Skala & Frekuensi & Persentase (\%) & Skor \\
\hline Sangat Setuju (SS) & 5 & 5 & 38,46 & 76,92 & 25 \\
Setuju (S) & 4 & 5 & 38,46 & & 9 \\
Netral (N) & 3 & 3 & 23,08 & & 9 \\
Tidak Setuju (TS) & 2 & 0 & 0,00 & 23,08 & 0 \\
Sangat Tidak Setuju (STS) & 1 & 0 & 0,00 & 0 \\
\hline Jumlah & 4,15 & 13 & $100,00 \quad 100,00$ & 54 \\
Rata-rata/Kriteria & \multicolumn{5}{c}{ Sangat baik } \\
\hline
\end{tabular}

Sumber : Hasil Pengolahan Data, 2017

Berdasarkan Tabel 2 diatas, mengenai pernyataan SAIBA dapat meningkatkan kinerja Anda menjawab sangat setuju dan setuju sebanyak 10 orang dengan persentase $76,92 \%$. Selain itu responden menjawab netral sebanyak 3 orang dengan persentase $23,08 \%$. Hal ini mengindikasikan bahwa SAIBA dapat meningkatkan kinerja responden.

\section{Tabel 3.}

Distribusi Frekuensi Tanggapan Responden tentang SAIBA dapat Meningkatkan Produktivitas Anda

\begin{tabular}{lccccc}
\hline \multicolumn{1}{c}{ Tanggapan } & Skala & Frekuensi & Persentase (\%) & Skor \\
\hline Sangat Setuju (SS) & 5 & 5 & 38,46 & 76,92 & 25 \\
Setuju (S) & 4 & 5 & 38,46 & & 20 \\
Netral (N) & 3 & 3 & 23,08 & \multirow{2}{*}{23,08} & 0 \\
Tidak Setuju (TS) & 2 & 0 & 0,00 & 0 \\
Sangat Tidak Setuju (STS) & 1 & 0 & 0,00 & & 0 \\
\hline Jumlah & 4,15 & 13 & 100,00 & 100,00 & 54 \\
Rata-rata/Kriteria & \multicolumn{5}{c}{ Baik } \\
\hline Sumber & \multicolumn{5}{c}{}
\end{tabular}

Sumber : Hasil Pengolahan Data, 2017

Berdasarkan tabel 3 mengenai pernyataan SAIBA dapat meningkatkan produktivitas Anda menjawab ssangat setuju dan setuju sebanyak 10 orang dengan persentase $76,92 \%$. Selain itu responden menjawab netral sebanyak 3 orang dengan persentase $23,08 \%$. Hal ini mengindikasikan bahwa SAIBA dapat meningkatkan produktivitas responden.

\section{Tabel 4.}


ISSN: 2302-8556

E-Jurnal Akuntansi Universitas Udayana Vol.24.3.September (2018):1768-1798

Distribusi Frekuensi Tanggapan Responden tentang SAIBA dapat Menambah Efektivitas Anda dalam Bekerja

\begin{tabular}{|c|c|c|c|c|c|}
\hline Tanggapan & Skala & Frekuensi & \multicolumn{2}{|c|}{ Persentase (\%) } & Skor \\
\hline Sangat Setuju (SS) & 5 & 6 & 46,15 & \multirow{2}{*}{76,92} & 30 \\
\hline Setuju (S) & 4 & 4 & 30,77 & & 16 \\
\hline Netral (N) & 3 & 3 & 23,08 & \multirow{3}{*}{23,08} & 9 \\
\hline Tidak Setuju (TS) & 2 & 0 & 0,00 & & 0 \\
\hline Sangat Tidak Setuju (STS) & 1 & 0 & 0,00 & & 0 \\
\hline Jumlah & & 13 & 100,00 & 100,00 & 55 \\
\hline Rata-rata/Kriteria & 4,23 & \multicolumn{4}{|c|}{ Sangat baik } \\
\hline
\end{tabular}

Sumber : Hasil Pengolahan Data, 2017

Berdasarkan Tabel 4 diatas, mengenai SAIBA dapat menambah efektivitas Anda dalam bekerja sebanyak 10 menjawab sangat setuju dan setuju sebanyak $76,92 \%$ dan netral sebanyak $23,08 \%$ yang berarti SAIBA mampu menambah efektivitas dalam bekerja.

Tabel 5.

Distribusi Frekuensi Tanggapan Responden tentang SAIBA Sangat Berguna bagi Anda

\begin{tabular}{|c|c|c|c|c|c|}
\hline Tanggapan & Skala & Frekuensi & Persent & $\%)$ & Skor \\
\hline Sangat Setuju (SS) & 5 & 7 & 53,85 & \multirow{2}{*}{84,62} & 35 \\
\hline Setuju $(S)$ & 4 & 4 & 30,77 & & 16 \\
\hline $\operatorname{Netral}(\mathrm{N})$ & 3 & 2 & 15,38 & \multirow{3}{*}{15,38} & 6 \\
\hline Tidak Setuju (TS) & 2 & 0 & 0,00 & & 0 \\
\hline Sangat Tidak Setuju (STS) & 1 & 0 & 0,00 & & 0 \\
\hline Jumlah & & 13 & 100,00 & 100,00 & 57 \\
\hline Rata-rata/Kriteria & 4,38 & \multicolumn{4}{|c|}{ Sangat baik } \\
\hline
\end{tabular}

Sumber : Hasil Pengolahan Data, 2017

Berdasarkan Tabel 5 diatas, mengenai pernyataan SAIBA sangat berguna bagi Anda mayoritas pegawai menjawab setuju dan sangat setuju sebanyak 11 orang dengan persentase $84,62 \%$. Selain itu responden menjawab netral sebanyak 2 orang dengan persentase $15,38 \%$. Secara keseluruhan mengindikasikan bahwa SAIBA sangat berguna bagi responden.

Tabel 6. 
Distribusi Frekuensi Tanggapan Responden tentang SAIBA Menjadikan Pekerjaan Anda Menjadi Lebih Mudah

\begin{tabular}{lccccc}
\hline \multicolumn{1}{c}{ Tanggapan } & Skala & Frekuensi & Persentase (\%) & Skor \\
\hline Sangat Setuju (SS) & 5 & 6 & 46,15 & \multirow{2}{*}{84,62} & 30 \\
Setuju (S) & 4 & 5 & 38.46 & & 6 \\
Netral (N) & 3 & 2 & 15,38 & \multirow{2}{*}{0} & 6,38 \\
Tidak Setuju (TS) & 2 & 0 & 0,00 & 0 \\
Sangat Tidak Setuju (STS) & 1 & 0 & 0,00 & 0 \\
\hline Jumlah & 4,31 & 13 & 100,00 & 100,00 & 56 \\
Rata-rata/Kriteria & \multicolumn{5}{c}{ Sangat baik } \\
\hline
\end{tabular}

Sumber : Hasil Pengolahan Data, 2017

Berdasarkan Tabel 6 diatas, mengenai pernyataan SAIBA menjadikan pekerjaan Anda menjadi lebih mudah mayoritas pegawai menjawab setuju dan sangat setuju sebanyak 11 orang dengan persentase 84,62\%. Selain itu responden menjawab netral sebanyak 2 orang dengan persentase 15,38\%. Secara keseluruhan mengindikasikan bahwa SAIBA menjadikan pekerjaan responden menjadi lebih mudah.

\section{Tabel 7.}

\begin{tabular}{clcc}
\multicolumn{4}{c}{ Rekapitulasi Tanggapan Responden pada Variabel Kegunaan SAIBA } \\
\hline No. & \multicolumn{1}{c}{ ITEM PERTANYAAN } & RATA-RATA & KRITERIA \\
\hline 1 & SAIBA membuat Anda dapat bekerja lebih cepat & 4,31 & Sangat baik \\
2 & SAIBA dapat meningkatkan kinerja Anda & 4,15 & Baik \\
3 & SAIBA dapat meningkatkan produktivitas Anda & 4,15 & Baik \\
4 & SAIBA dapat menambah efektivitas Anda dalam & 4,23 & Sangat baik \\
5 & bekerja & 4,38 & Sangat baik \\
5 & SAIBA sangat berguna bagi Anda & 4,31 & Sangat baik \\
\hline & SAIBA menjadikan pekerjaan Anda menjadi lebih & 4,26 & Sangat baik \\
& mudah & 4,38 & Sangat baik \\
\multicolumn{4}{c}{ Skor Rata-Rata } \\
\multicolumn{2}{c}{ Skor Maksimum } & 4,15 & Baik \\
\hline
\end{tabular}

Sumber : Hasil Pengolahan Data, 2017

Berdasarkan tabel 7 hasil deskripsi atas tanggapan responden terhadap item pernyataan dari variabel kegunaan SAIBA menghasilkan skor rata-rata sebesar 4,26 dengan skor maksimum 4,38 pada item pernyataan "SAIBA sangat berguna bagi 
ISSN: 2302-8556

E-Jurnal Akuntansi Universitas Udayana Vol.24.3.September (2018):1768-1798

Anda" dan skor minimum 4,15 pada item pernyataan "SAIBA dapat meningkatkan kinerja Anda" dan "SAIBA dapat meningkatkan produktivitas Anda".

Tabel 8.

Distribusi Frekuensi Tanggapan Responden tentang SAIBA Mudah untuk Dipelajari

\begin{tabular}{|c|c|c|c|c|c|}
\hline Tanggapan & Skala & Frekuensi & Persel & $\%)$ & Skor \\
\hline Sangat Setuju (SS) & 5 & 4 & 30,77 & \multirow{2}{*}{84,62} & 20 \\
\hline Setuju (S) & 4 & 7 & 53,85 & & 28 \\
\hline Netral (N) & 3 & 2 & 15,38 & \multirow{3}{*}{15,38} & 6 \\
\hline Tidak Setuju (TS) & 2 & 0 & 0,00 & & 0 \\
\hline Sangat Tidak Setuju (STS) & 1 & 0 & 0,00 & & 0 \\
\hline Jumlah & & 13 & 100,00 & 100,00 & 54 \\
\hline Rata-rata/Kriteria & 4,15 & \multicolumn{4}{|c|}{ Baik } \\
\hline
\end{tabular}

Sumber : Hasil Pengolahan Data, 2017

Berdasarkan Tabel 8 diatas, mengenai pernyataan SAIBA mudah untuk dipelajari mayoritas pegawai menjawab setuju dan sangat setuju sebanyak 11 orang dengan persentase $84,62 \%$. Selain itu responden menjawab netral sebanyak 2 orang dengan persentase $15,38 \%$. Secara keseluruhan mengindikasikan bahwa SAIBA mudah untuk dipelajari.

Tabel 9.

Distribusi Frekuensi Tanggapan Responden tentang SAIBA Mudah untuk Dikontrol/ Dikendalikan

\begin{tabular}{|c|c|c|c|c|c|}
\hline Tanggapan & Skala & Frekuensi & \multicolumn{2}{|c|}{ Persentase (\%) } & Skor \\
\hline Sangat Setuju (SS) & 5 & 6 & 46,15 & \multirow{2}{*}{76,92} & 30 \\
\hline Setuju (S) & 4 & 4 & 30,77 & & 16 \\
\hline Netral (N) & 3 & 3 & 23,08 & \multirow{3}{*}{23,08} & 9 \\
\hline Tidak Setuju (TS) & 2 & 0 & 0,00 & & 0 \\
\hline Sangat Tidak Setuju (STS) & 1 & 0 & 0,00 & & 0 \\
\hline Jumlah & & 13 & 100,00 & 100,00 & 55 \\
\hline Rata-rata/Kriteria & 4,23 & \multicolumn{4}{|c|}{ Sangat baik } \\
\hline
\end{tabular}

Sumber : Hasil Pengolahan Data, 2017

Berdasarkan Tabel 9, mengenai pernyataan SAIBA mudah untuk dikontrol / dikendalikan mayoritas responden menjawab setuju dan sangat setuju sebanyak 10 orang dengan persentase $76,92 \%$. Selain itu responden menjawab netral sebanyak 3 
orang dengan persentase $23,08 \%$. Secara keseluruhan mengindikasikan bahwa SAIBA mudah untuk dikontrol / dikendalikan.

Tabel 10.

Distribusi Frekuensi Tanggapan Responden tentang SAIBA Merupakan Aplikasi Yang Jelas dan Mudah Dimengerti

\begin{tabular}{lccccc}
\hline \multicolumn{1}{c}{ Tanggapan } & Skala & Frekuensi & Persentase (\%) & Skor \\
\hline Sangat Setuju (SS) & 5 & 9 & 69,23 & 76,92 & 45 \\
Setuju (S) & 4 & 1 & 7,69 & & 9 \\
Netral (N) & 3 & 3 & 23,08 & \multirow{2}{*}{23,08} & 0 \\
Tidak Setuju (TS) & 2 & 0 & 0,00 & 0 \\
Sangat Tidak Setuju (STS) & 1 & 0 & 0,00 & $100,00 \quad 100,00$ & 58 \\
\hline Jumlah & 4,46 & 13 & \multicolumn{5}{c}{ Sangat baik } \\
Rata-rata/Kriteria & \multicolumn{5}{c}{} \\
\hline
\end{tabular}

Sumber : Hasil Pengolahan Data, 2017

Berdasarkan Tabel 10, mengenai pernyataan SAIBA merupakan aplikasi yang jelas dan mudah dimengerti mayoritas responden menjawab setuju dan sangat setuju sebanyak 10 orang dengan persentase $76,92 \%$. Selain itu responden menjawab netral sebanyak 3 orang dengan persentase $23,08 \%$. Secara keseluruhan mengindikasikan bahwa SAIBA merupakan aplikasi yang jelas dan mudah dimengerti.

Tabel 11.

Distribusi Frekuensi Tanggapan Responden tentang SAIBA Merupakan Aplikasi yang Fleksibel

\begin{tabular}{lccccc}
\hline \multicolumn{1}{c}{ Tanggapan } & Skala & Frekuensi & Persentase (\%) & Skor \\
\hline Sangat Setuju (SS) & 5 & 9 & 69,23 & \multirow{2}{*}{84,62} & 45 \\
Setuju (S) & 4 & 2 & 15,38 & & 6 \\
Netral (N) & 3 & 2 & 15,38 & \multirow{2}{*}{15,38} & 0 \\
Tidak Setuju (TS) & 2 & 0 & 0,00 & 0 \\
Sangat Tidak Setuju (STS) & 1 & 0 & 0,00 & & 59 \\
\hline Jumlah & 4,54 & 13 & 100,00 & 100,00 & 59 \\
Rata-rata/Kriteria & \multicolumn{5}{c}{ Sangat baik } \\
\hline
\end{tabular}

Sumber : Hasil Pengolahan Data, 2017

Berdasarkan Tabel 11 mengenai pernyataan SAIBA merupakan aplikasi yang fleksibel mayoritas responden menjawab setuju dan sangat setuju sebanyak 11 orang dengan persentase $84,62 \%$. Selain itu responden menjawab netral sebanyak 2 orang 
ISSN: 2302-8556

E-Jurnal Akuntansi Universitas Udayana Vol.24.3.September (2018):1768-1798

dengan persentase $15,38 \%$. Secara keseluruhan mengindikasikan bahwa SAIBA merupakan aplikasi yang fleksibel.

Tabel 12.

Distribusi Frekuensi Tanggapan Responden tentang Anda dapat dengan Mudah untuk Jadi Terampil Menggunakan Aplikasi SAIBA

\begin{tabular}{|c|c|c|c|c|c|}
\hline Tanggapan & Skala & Frekuensi & \multicolumn{2}{|c|}{ Persentase (\%) } & Skor \\
\hline Sangat Setuju (SS) & 5 & 8 & 61,54 & \multirow{3}{*}{76,92} & 40 \\
\hline Setuju (S) & 4 & 2 & 15,38 & & 8 \\
\hline Netral (N) & 3 & 3 & 23,08 & & 9 \\
\hline Tidak Setuju (TS) & 2 & 0 & 0,00 & \multirow[t]{2}{*}{23,08} & 0 \\
\hline Sangat Tidak Setuju (STS) & 1 & 0 & 0,00 & & 0 \\
\hline Jumlah & & 13 & 100,00 & 100,00 & 57 \\
\hline Rata-rata/Kriteria & 4,38 & \multicolumn{4}{|c|}{ Sangat baik } \\
\hline
\end{tabular}

Sumber : Hasil Pengolahan Data, 2017

Berdasarkan Tabel 12 diatas, mengenai pernyataan Anda dapat dengan mudah untuk jadi terampil menggunakan aplikasi SAIBA mayoritas pegawai menjawab setuju dan sangat setuju sebanyak 10 orang dengan persentase $76,92 \%$. Selain itu responden menjawab netral sebanyak 3 orang dengan persentase 23,08\%. Secara keseluruhan mengindikasikan bahwa responden dapat dengan mudah untuk jadi terampil menggunakan aplikasi SAIBA.

Tabel 13.

Distribusi Frekuensi Tanggapan Responden tentang SAIBA Mudah Digunakan

\begin{tabular}{lccccc}
\hline \multicolumn{1}{c}{ Tanggapan } & Skala & Frekuensi & Persentase (\%) & Skor \\
\hline Sangat Setuju (SS) & 5 & 7 & 53,85 & 76,92 & 35 \\
Setuju (S) & 4 & 3 & 23,08 & 12 \\
Netral (N) & 3 & 3 & 23,08 & 9 \\
Tidak Setuju (TS) & 2 & 0 & 0,00 & 23,08 & 0 \\
Sangat Tidak Setuju (STS) & 1 & 0 & 0,00 & 0 \\
\hline Jumlah & 4,31 & 13 & $100,00 \quad 100,00$ & 56 \\
Rata-rata/Kriteria & \multicolumn{3}{c}{ Sangat baik } \\
\hline
\end{tabular}

Sumber : Hasil Pengolahan Data, 2017

Berdasarkan Tabel 13 diatas, mengenai pernyataan SAIBA mudah digunakan mayoritas responden menjawab setuju dan sangat setuju sebanyak 10 orang dengan 
persentase $76,92 \%$. Selain itu responden menjawab netral sebanyak 3 orang dengan persentase 23,08\%. Secara keseluruhan mengindikasikan bahwa SAIBA mudah digunakan.

Tabel 14.

\begin{tabular}{|c|c|c|c|}
\hline No. & $\begin{array}{l}\text { ITEM PERTANYAAN } \\
\end{array}$ & RATA-RATA & KRITERIA \\
\hline 7 & SAIBA mudah untuk dipelajari & 4,15 & Baik \\
\hline 8 & SAIBA mudah untuk dikontrol/ dikendalikan & 4,23 & Sangat baik \\
\hline 9 & $\begin{array}{l}\text { SAIBA merupakan aplikasi yang jelas dan mudah } \\
\text { dimengerti }\end{array}$ & 4,46 & Sangat baik \\
\hline 10 & SAIBA merupakan aplikasi yang fleksibel & 4,54 & Sangat baik \\
\hline 11 & $\begin{array}{l}\text { Anda dapat dengan mudah untuk jadi terampil } \\
\text { menggunakan aplikasi SAIBA }\end{array}$ & 4,38 & Sangat baik \\
\hline 12 & SAIBA mudah digunakan & 4,31 & Sangat baik \\
\hline & Skor Rata-Rata & 4,35 & Sangat baik \\
\hline & Skor Maksimum & 4,54 & Sangat baik \\
\hline & Skor Minimum & 4,15 & Baik \\
\hline
\end{tabular}

Sumber : Hasil Pengolahan Data, 2017

Berdasarkan tabel 14 hasil deskripsi atas tanggapan responden terhadap item pernyataan dari variabel kemudahan penggunaan SAIBA menghasilkan skor rata-rata sebesar 4,35 dengan skor maksimum 4,54 pada pernyataan "SAIBA merupakan aplikasi yang fleksibel" dan dan skor minimum 4,15 pada pernyataan "SAIBA mudah untuk dipelajari”.

Tabel 15.

Distribusi Frekuensi Tanggapan Responden tentang Informasi yang Ada dalam Laporan Keuangan sesuai dengan Harapan dan Kebutuhan

\begin{tabular}{lccccc}
\hline \multicolumn{1}{c}{ Tanggapan } & Skala & Frekuensi & Persentase (\%) & Skor \\
\hline Sangat Setuju (SS) & 5 & 6 & 46,15 & 92,31 & 30 \\
Setuju (S) & 4 & 6 & 46,15 & & 24 \\
Netral (N) & 3 & 1 & 7,69 & 7,69 & 0 \\
Tidak Setuju (TS) & 2 & 0 & 0,00 & 0 \\
Sangat Tidak Setuju (STS) & 1 & 0 & 0,00 & $100,00 \quad 100,00$ & 57 \\
\hline Jumlah & 4,38 & 13 & \multicolumn{3}{c}{ Sangat baik } \\
Rata-rata/Kriteria & \multicolumn{5}{c}{} \\
\hline
\end{tabular}

Sumber : Hasil Pengolahan Data, 2017 
ISSN: 2302-8556

E-Jurnal Akuntansi Universitas Udayana Vol.24.3.September (2018):1768-1798

Berdasarkan Tabel 15 mengenai pernyataan informasi yang ada dalam laporan keuangan sesuai dengan harapan dan kebutuhan mayoritas responden menjawab sangat setuju dan setuju sebanyak 12 orang dengan persentase 92,31\%. Sedangkan netral, tidak setuju dan sangat tidak setuju sebanyak 1 orang dengan persentase 7,69\%. Hal ini mengindikasikan bahwa informasi yang ada dalam laporan keuangan sesuai dengan harapan dan kebutuhan.

Tabel 16.

Distribusi Frekuensi Tanggapan Responden tentang Laporan Keuangan yang Dihasilkan dapat Membantu dalam Memperkirakan Aktivitas yang Berhubungan dengan Keuangan pada Periode Berikutnya

\begin{tabular}{lccccc}
\hline \multicolumn{1}{c}{ Tanggapan } & Skala & Frekuensi & Persentase (\%) & Skor \\
\hline Sangat Setuju (SS) & 5 & 7 & 53,85 & 84,62 & 35 \\
Setuju (S) & 4 & 4 & 30,77 & & 16 \\
Netral (N) & 3 & 2 & 15,38 & \multirow{2}{*}{0,38} & 0 \\
Tidak Setuju (TS) & 2 & 0 & 0,00 & 0 \\
Sangat Tidak Setuju (STS) & 1 & 0 & 0,00 & 0 \\
\hline Jumlah & 4,38 & 13 & $100,00 \quad 100,00$ & 57 \\
Rata-rata/Kriteria & \multicolumn{5}{c}{ Sangat baik } \\
\hline
\end{tabular}

Sumber : Hasil Pengolahan Data, 2017

Berdasarkan Tabel 16 diatas, mengenai pernyataan laporan keuangan yang dihasilkan dapat membantu dalam memperkirakan aktivitas yang berhubungan dengan keuangan pada periode berikutnya mayoritas responden menjawab sangat setuju dan setuju sebanyak 11 orang dengan persentase $84,62 \%$. Sedangkan netral, tidak setuju dan sangat tidak setuju sebanyak 2 orang dengan persentase $15,38 \%$. Hal ini mengindikasikan bahwa laporan keuangan yang dihasilkan dapat membantu dalam memperkirakan aktivitas yang berhubungan dengan keuangan pada periode berikutnya. 
Tabel 17.

Distribusi Frekuensi Tanggapan Responden tentang Laporan Keuangan dapat Membantu dalam Pengambilan Keputusan

\begin{tabular}{lccccc}
\hline \multicolumn{1}{c}{ Tanggapan } & Skala & Frekuensi & Persentase (\%) & Skor \\
\hline Sangat Setuju (SS) & 5 & 9 & 69,23 & 84,62 & 45 \\
Setuju (S) & 4 & 2 & 15,38 & & 8 \\
Netral (N) & 3 & 2 & 15,38 & & 6 \\
Tidak Setuju (TS) & 2 & 0 & 0,00 & 15,38 & 0 \\
Sangat Tidak Setuju (STS) & 1 & 0 & 0,00 & 0 \\
\hline Jumlah & 4,54 & 13 & \multicolumn{2}{c}{$100,00 \quad 100,00$} & 59 \\
Rata-rata/Kriteria & \multicolumn{5}{c}{ Sangat baik } \\
\hline
\end{tabular}

Sumber : Hasil Pengolahan Data, 2017

Berdasarkan Tabel 17 diatas, mengenai pernyataan laporan keuangan dapat membantu dalam pengambilan keputusan mayoritas responden menjawab sangat setuju dan setuju sebanyak 11 orang dengan persentase $84,62 \%$. Sedangkan netral, tidak setuju dan sangat tidak setuju sebanyak 2 orang dengan persentase 15,38\%. Hal ini mengindikasikan bahwa ruang laporan keuangan dapat membantu dalam pengambilan keputusan.

Tabel 18.

Distribusi Frekuensi Tanggapan Responden tentang Laporan Keuangan yang Berkualitas Memenuhi Persyaratan Normatif yaitu Relevan, Andal, Dapat Dipercaya, dan Dapat Dibandingkan

\begin{tabular}{lccccc}
\hline \multicolumn{1}{c}{ Tanggapan } & Skala & Frekuensi & Persentase (\%) & Skor \\
\hline Sangat Setuju (SS) & 5 & 7 & 53,85 & 92,31 & 35 \\
Setuju (S) & 4 & 5 & 38,46 & & 20 \\
Netral (N) & 3 & 1 & 7,69 & 7,69 & 0 \\
Tidak Setuju (TS) & 2 & 0 & 0,00 & 0 \\
Sangat Tidak Setuju (STS) & 1 & 0 & 0,00 & 58 \\
\hline Jumlah & 4,46 & 13 & $100,00 \quad 100,00$ & 58 \\
Rata-rata/Kriteria & \multicolumn{5}{c}{ Sangat baik } \\
\hline
\end{tabular}

Sumber : Hasil Pengolahan Data, 2017

Berdasarkan Tabel 18, mengenai pernyataan laporan keuangan yang berkualitas memenuhi persyaratan normatif yaitu relevan, andal, dapat dipercaya, dan dapat dibandingkan mayoritas responden menjawab sangat setuju dan setuju 
ISSN: 2302-8556

E-Jurnal Akuntansi Universitas Udayana Vol.24.3.September (2018):1768-1798

sebanyak 12 orang dengan persentase 92,31\%. Sedangkan netral, tidak setuju dan sangat tidak setuju sebanyak 1 orang dengan persentase 7,69\%. Hal ini mengindikasikan bahwa laporan keuangan yang berkualitas memenuhi persyaratan normatif yaitu relevan, andal, dapat dipercaya, dan dapat dibandingkan.

Tabel 19.

Distribusi Frekuensi Tanggapan Responden tentang Setiap Informasi dalam Laporan Keuangan disertai dengan Penjelasan yang Rinci sehingga Kekeliruan dalam Interpretasi dan Penggunaan Informasi Tersebut dapat Dicegah

\begin{tabular}{lccccc}
\hline \multicolumn{1}{c}{ Tanggapan } & Skala & Frekuensi & Persentase (\%) & Skor \\
\hline Sangat Setuju (SS) & 5 & 5 & 38,46 & 100,00 & 25 \\
Setuju (S) & 4 & 8 & 61,54 & & 0 \\
Netral (N) & 3 & 0 & 0,00 & 0,00 & 0 \\
Tidak Setuju (TS) & 2 & 0 & 0,00 & 0 \\
Sangat Tidak Setuju (STS) & 1 & 0 & 0,00 & $100,00 \quad 100,00$ & 57 \\
\hline Jumlah & 4,38 & 13 & \multicolumn{3}{c}{ Sangat baik } \\
Rata-rata/Kriteria & \multicolumn{5}{c}{} \\
\hline
\end{tabular}

Sumber : Hasil Pengolahan Data, 2017

Berdasarkan Tabel 19 diatas, mengenai pernyataan setiap informasi dalam laporan keuangan disertai dengan penjelasan yang rinci sehingga kekeliruan dalam interpretasi dan penggunaan informasi tersebut dapat dicegah., seluruh responden menjawab sangat setuju dan setuju sebanyak 13 orang dengan persentase $100,00 \%$. Hal ini mengindikasikan bahwa setiap informasi dalam laporan keuangan disertai dengan penjelasan yang rinci sehingga kekeliruan dalam interpretasi dan penggunaan informasi tersebut dapat dicegah. 
Tabel 20.

Distribusi Frekuensi Tanggapan Responden tentang Informasi dalam Laporan Keuangan Telah Menggambarkan Secara Jujur Semua Transaksi dan Peristiwa Lainnya yang Seharusnya Disajikan

\begin{tabular}{|c|c|c|c|c|c|}
\hline Tanggapan & Skala & Frekuensi & Persent: & $\%)$ & Skor \\
\hline Sangat Setuju (SS) & 5 & 5 & 38,46 & \multirow{2}{*}{84,62} & 25 \\
\hline Setuju (S) & 4 & 6 & 46,15 & & 24 \\
\hline Netral (N) & 3 & 2 & 15,38 & \multirow{3}{*}{15,38} & 6 \\
\hline Tidak Setuju (TS) & 2 & 0 & 0,00 & & 0 \\
\hline Sangat Tidak Setuju (STS) & 1 & 0 & 0,00 & & 0 \\
\hline Jumlah & & 13 & 100,00 & 100,00 & 55 \\
\hline Rata-rata/Kriteria & 4,23 & \multicolumn{4}{|c|}{ Sangat baik } \\
\hline
\end{tabular}

Sumber : Hasil Pengolahan Data, 2017

Berdasarkan Tabel 20 diatas, mengenai pernyataan informasi dalam laporan keuangan telah menggambarkan secara jujur semua transaksi dan peristiwa lainnya yang seharusnya disajikan, mayoritas responden menjawab sangat setuju dan setuju sebanyak 11 orang dengan persentase $84,62 \%$. Sedangkan netral, tidak setuju dan sangat tidak setuju sebanyak 2 orang dengan persentase 15,38\%. Hal ini mengindikasikan bahwa informasi dalam laporan keuangan telah menggambarkan secara jujur semua transaksi dan peristiwa lainnya yang seharusnya disajikan.

Tabel 21.

Distribusi Frekuensi Tanggapan Responden tentang Informasi yang Disajikan dalam Laporan Keuangan dapat Diuji, dan Apabila Pengujian Dilakukan oleh Pihak yang Berbeda, Hasilnya Tetap Menunjukkan Simpulan yang Tidak Berbeda Jauh

\begin{tabular}{lccccc}
\hline \multicolumn{1}{c}{ Tanggapan } & Skala & Frekuensi & Persentase (\%) & Skor \\
\hline Sangat Setuju (SS) & 5 & 7 & 53,85 & 76,92 & 35 \\
Setuju (S) & 4 & 3 & 23,08 & & 12 \\
Netral (N) & 3 & 3 & 23,08 & \\
Tidak Setuju (TS) & 2 & 0 & 0,00 & 23,08 & 0 \\
Sangat Tidak Setuju (STS) & 1 & 0 & 0,00 & 0 \\
\hline Jumlah & 4,31 & 13 & 100,00 & 100,00 & 56 \\
Rata-rata/Kriteria & \multicolumn{5}{c}{ Sangat baik } \\
\hline
\end{tabular}

Sumber : Hasil Pengolahan Data, 2017 
ISSN: 2302-8556

E-Jurnal Akuntansi Universitas Udayana Vol.24.3.September (2018):1768-1798

Berdasarkan Tabel 21 diatas, mengenai pernyataan Informasi yang disajikan dalam laporan keuangan dapat diuji, dan apabila pengujian dilakukan oleh pihak yang berbeda, hasilnya tetap menunjukkan simpulan yang tidak berbeda jauh, mayoritas responden menjawab sangat setuju dan setuju sebanyak 10 orang dengan persentase 76,92\%. Sedangkan netral, tidak setuju dan sangat tidak setuju sebanyak 3 orang dengan persentase $23,08 \%$. Hal ini mengindikasikan bahwa informasi yang disajikan dalam laporan keuangan dapat diuji, dan apabila pengujian dilakukan oleh pihak yang berbeda, hasilnya tetap menunjukkan simpulan yang tidak berbeda jauh.

Tabel 22.

Distribusi Frekuensi Tanggapan Responden tentang Seluruh Informasi yang Disajikan dalam Laporan Keuangan (Neraca, LRA, dan CaLK) dapat Dipahami dengan Mudah

\begin{tabular}{lccccc}
\hline \multicolumn{1}{c}{ Tanggapan } & Skala & Frekuensi & Persentase (\%) & Skor \\
\hline Sangat Setuju (SS) & 5 & 5 & 38,46 & 84,62 & 25 \\
Setuju (S) & 4 & 6 & 46,15 & & 24 \\
Netral (N) & 3 & 2 & 15,38 & & 6 \\
Tidak Setuju (TS) & 2 & 0 & 0,00 & 15,38 & 0 \\
Sangat Tidak Setuju (STS) & 1 & 0 & 0,00 & 0 \\
\hline Jumlah & 4,23 & 13 & $100,00 \quad 100,00$ & 55 \\
Rata-rata/Kriteria & \multicolumn{5}{c}{ Sangat baik } \\
\hline
\end{tabular}

Sumber : Hasil Pengolahan Data, 2017

Berdasarkan Tabel 22 diatas, mengenai pernyataan seluruh informasi yang disajikan dalam laporan keuangan (Neraca, LRA, dan CaLK) dapat dipahami dengan mudah, mayoritas responden menjawab sangat setuju dan setuju sebanyak 11 orang dengan persentase $84,62 \%$. Sedangkan netral, tidak setuju dan sangat tidak setuju sebanyak 2 orang dengan persentase 15,38\%. Hal ini mengindikasikan bahwa seluruh informasi yang disajikan dalam laporan keuangan (Neraca, LRA, dan CaLK) dapat dipahami dengan mudah. 
Tabel 23.

\begin{tabular}{|c|c|c|c|c|c|}
\hline Tanggapan & Skala & Frakunci & & & Skor \\
\hline Sangat Setuju (SS) & 5 & 9 & 69,23 & \multirow[b]{2}{*}{100,00} & 45 \\
\hline Setuju (S) & 4 & 4 & 30,77 & & 16 \\
\hline Netral $(\mathrm{N})$ & 3 & 0 & 0,00 & \multirow{3}{*}{0,00} & 0 \\
\hline Tidak Setuju (TS) & 2 & 0 & 0,00 & & 0 \\
\hline Sangat Tidak Setuju (STS) & 1 & 0 & 0,00 & & 0 \\
\hline Jumlah & & 13 & 100,00 & 100,00 & 61 \\
\hline Rata-rata/Kriteria & 4,69 & \multicolumn{4}{|c|}{ Sangat baik } \\
\hline
\end{tabular}

Sumber : Hasil Pengolahan Data, 2017

Berdasarkan Tabel 23 diatas, mengenai pernyataan informasi dalam laporan keuangan dinyatakan dalam istilah yang mudah dipahami, seluruh responden menjawab sangat setuju dan setuju sebanyak 13 orang dengan persentase $100,00 \%$. Hal ini mengindikasikan bahwa informasi dalam laporan keuangan dinyatakan dalam istilah yang mudah dipahami.

Tabel 24.

\begin{tabular}{|c|c|c|c|}
\hline \multicolumn{4}{|c|}{ Rekapitulasi Tanggapan Responden Mengenai Kualitas Laporan Keuangan } \\
\hline No. & ITEM PERTANYAAN & RATA-RATA & KRITERIA \\
\hline \multicolumn{4}{|c|}{ Relevan } \\
\hline 1 & $\begin{array}{l}\text { Informasi yang ada dalam laporan keuangan sesuai dengan } \\
\text { harapan dan kebutuhan }\end{array}$ & 4,38 & Sangat baik \\
\hline 2 & $\begin{array}{l}\text { Laporan keuangan yang dihasilkan dapat membantu dalam } \\
\text { memperkirakan aktivitas yang berhubungan dengan keuangan } \\
\text { pada periode berikutnya }\end{array}$ & 4,38 & Sangat baik \\
\hline 3 & $\begin{array}{l}\text { Laporan keuangan dapat membantu dalam pengambilan } \\
\text { keputusan }\end{array}$ & 4,54 & Sangat baik \\
\hline & Skor Rata-Rata & 4,43 & Sangat baik \\
\hline No. & ITEM PERTANYAAN & RATA-RATA & KRITERIA \\
\hline \multicolumn{4}{|c|}{ Andal } \\
\hline 4 & $\begin{array}{l}\text { Laporan keuangan yang berkualitas memenuhi persyaratan } \\
\text { normatif yaitu relevan, andal, dapat dipercaya, dan dapat } \\
\text { dibandingkan }\end{array}$ & 4,46 & Sangat baik \\
\hline 5 & $\begin{array}{l}\text { Setiap informasi dalam laporan keuangan disertai dengan } \\
\text { penjelasan yang rinci sehingga kekeliruan dalam interpretasi } \\
\text { dan penggunaan informasi tersebut dapat dicegah. }\end{array}$ & 4,38 & Sangat baik \\
\hline 6 & $\begin{array}{l}\text { Informasi dalam laporan keuangan telah menggambarkan } \\
\text { secara jujur semua transaksi dan peristiwa lainnya yang } \\
\text { seharusnya disajikan }\end{array}$ & 4,23 & Sangat baik \\
\hline & Skor Rata-Rata & 4,36 & Sangat baik \\
\hline
\end{tabular}


ISSN: 2302-8556

E-Jurnal Akuntansi Universitas Udayana Vol.24.3.September (2018):1768-1798

\begin{tabular}{|c|c|c|c|}
\hline No. & ITEM PERTANYAAN & RATA-RATA & KRITERIA \\
\hline \multicolumn{4}{|c|}{ Dapat dibandingkan } \\
\hline 7 & $\begin{array}{l}\text { Informasi yang disajikan dalam laporan keuangan dapat diuji, } \\
\text { dan apabila pengujian dilakukan oleh pihak yang berbeda, } \\
\text { hasilnya tetap menunjukkan simpulan yang tidak berbeda jauh }\end{array}$ & 4,31 & Sangat baik \\
\hline 8 & $\begin{array}{l}\text { Seluruh informasi yang disajikan dalam laporan keuangan } \\
\text { (Neraca, LRA, dan CaLK) dapat dipahami dengan mudah }\end{array}$ & 4,23 & Sangat baik \\
\hline & Skor Rata-Rata & 4,27 & \\
\hline No. & ITEM PERTANYAAN & RATA-RATA & KRITERIA \\
\hline \multicolumn{4}{|c|}{ Dapat dipahami } \\
\hline 9 & $\begin{array}{l}\text { Informasi dalam laporan keuangan dinyatakan dalam istilah } \\
\text { yang mudah dipahami }\end{array}$ & 4,69 & Sangat baik \\
\hline & Skor Rata-Rata & 4,69 & Sangat baik \\
\hline & Jumlah & 17,75 & \\
\hline & Rata-rata/Kriteria & 4,44 & Sangat baik \\
\hline & Skor Maksimum & 4,69 & Sangat baik \\
\hline & Skor Minimum & 4,23 & Sangat baik \\
\hline
\end{tabular}

Sumber : Hasil Pengolahan Data, 2017

Berdasarkan tabel 24 hasil deskripsi atas tanggapan responden terhadap item pernyataan dari variabel kualitas laporan keuangan menghasilkan skor rata-rata sebesar 4,44 dengan skor maksimum 4,69 dan skor minimum 4,23. Dalam dimensi relevan menghasilkan skor rata-rata 4,43, dimensi andal menghasilkan skor rata-rata 4,36, dimensi dapat dibandingkan menghasilkan skor rata-rata 4,27 dan dimensi dapat dipahami menghasilkan skor rata-rata 4,69.

Tabel 25.

Rekapitulasi Hasil Variabel Kegunaan Persepsian

\begin{tabular}{lccc}
\hline Pernyataan & r korelasi & r kritis & keterangan \\
\hline Pernyataan 1 & 0,802 & 0,553 & valid \\
Pernyataan 2 & 0,846 & 0,553 & valid \\
Pernyataan 3 & 0,899 & 0,553 & valid \\
Pernyataan 4 & 0,928 & 0,553 & valid \\
Pernyataan 5 & 0,837 & 0,553 & valid \\
Pernyataan 6 & 0,815 & 0,553 & valid
\end{tabular}

Sumber : Hasil Pengolahan Data, 2017 
Tabel 26.

\begin{tabular}{lccc}
\multicolumn{4}{c}{ Rekapitulasi Hasil Variabel Kemudahan Penggunaan Persepsian } \\
\hline \multicolumn{1}{c}{ Pernyataan } & r korelasi & r kritis & keterangan \\
\hline Pernyataan 7 & 0,792 & 0,553 & valid \\
Pernyataan 8 & 0,927 & 0,553 & valid \\
Pernyataan 9 & 0,896 & 0,553 & valid \\
Pernyataan 10 & 0,937 & 0,553 & valid \\
Pernyataan 11 & 0,949 & 0,553 & valid \\
Pernyataan 12 & 0,878 & 0,553 & valid \\
\hline
\end{tabular}

Sumber : Hasil Pengolahan Data, 2017

Tabel 27. Rekapitulasi Hasil Variabel Kualitas Laporan Keuangan

\begin{tabular}{lccc}
\hline Pernyataan & r korelasi & r kritis & keterangan \\
\hline Pernyataan 1 & 0,688 & 0,553 & valid \\
Pernyataan 2 & 0,917 & 0,553 & valid \\
Pernyataan 3 & 0,821 & 0,553 & valid \\
Pernyataan 4 & 0,744 & 0,553 & valid \\
Pernyataan 5 & 0,682 & 0,553 & valid \\
Pernyataan 6 & 0,816 & 0,553 & valid \\
Pernyataan 7 & 0,923 & 0,553 & valid \\
Pernyataan 8 & 0,851 & 0,553 & valid \\
Pernyataan 9 & 0,866 & 0,553 & valid \\
\hline
\end{tabular}

Sumber : Hasil Pengolahan Data, 2017

Pada ketiga tabel 25-27 di atas terlihat bahwa seluruh item pernyataan pada masing-masing variabel memiliki koefisien validitas yang lebih besar dari $\mathrm{r}$ tabel sehingga seluruh item layak digunakan sebagai alat ukur dalam penelitian.

Tabel 28.

Hasil Uji Reliabilitas Kuesioner Penelitian

\begin{tabular}{lccc}
\hline \multicolumn{1}{c}{ Variabel } & $\begin{array}{c}\text { Indeks } \\
\text { reliabilitas }\end{array}$ & $\begin{array}{c}\text { Nilai } \\
\text { kritis }\end{array}$ & Keterangan \\
\hline Kegunaan persepsian & 0,926 & 0,7 & Reliabel \\
Kemudahan penggunaan persepsian & 0,951 & 0,7 & Reliabel \\
Kualitas Laporan Keuangan & 0,938 & 0,7 & Reliabel \\
\hline
\end{tabular}

Sumber : Hasil Pengolahan Data, 2017

Nilai reliabilitas butir pernyataan pada kuesioner masing-masing variabel yang sedang diteliti lebih besar dari 0,70. Hasil ini menunjukkan bahwa butir-butir pertanyaan pada kuesioner andal untuk mengukur variabelnya. 
ISSN: 2302-8556

E-Jurnal Akuntansi Universitas Udayana

Vol.24.3.September (2018):1768-1798

Tabel 29.

Pedoman untuk memberikan interprestasi terhadap Koefisien Korelasi

\begin{tabular}{cl}
\hline $\begin{array}{c}\text { Interval Korelasi } \\
\text { (Skema Penilaian) }\end{array}$ & \multicolumn{1}{c}{$\begin{array}{c}\text { Tingkat hubungan } \\
\text { (Kriteria) }\end{array}$} \\
\hline $0,00-0,19$ & Sangat Kurang Baik \\
$0,20-0,39$ & Kurang Baik \\
$0,40-0,59$ & Cukup Baik \\
$0,60-0,79$ & Baik \\
$0,80-1,00$ & Sangat Baik \\
\hline
\end{tabular}

Sumber : Hasil Pengolahan Data, 2017

Bila $r$ koefisien ini mendekati 0 (nol), maka hubungan antara kegunaan dan kemudahan penggunaan Sistem Aplikasi Akuntansi Instansi Berbasis Akrual (SAIBA) dengan kualitas laporan keuangan sangat lemah. Bila $r=1$ adalah mendekati 1, maka hubungan hubungan antara kegunaan dan kemudahan penggunaan Sistem Aplikasi Akuntansi Instansi Berbasis Akrual (SAIBA) dengan kualitas laporan keuangan sangat kuat dan mempunyai hubungan searah atau positif, artinya jika variabel $\mathrm{X}$ mengalami penurunan maka akan diikuti penurunan variabel $\mathrm{Y}$, begitu juga sebaliknya. Bila $r=-1$ adalah mendekati -1 , maka hubungan antara hubungan antara kegunaan dan kemudahan penggunaan Sistem Aplikasi Akuntansi Instansi Berbasis Akrual (SAIBA) dengan kualitas laporan keuangan sangat kuat dan mempunyai hubungan yang tidak searah atau negatif, artinya jika jika variabel $\mathrm{X}$ mengalami kenaikan maka akan diikuti penurunan variabel $\mathrm{Y}$, begitu juga sebaliknya.

Tabel 30.

Hubungan kegunaan SAIBA dengan kualitas laporan keuangan

\begin{tabular}{cccccc}
\hline $\mathbf{r}_{\text {s }}$ & $\mathbf{t}_{\text {-hitung }}$ & $\mathbf{t}_{\text {-tabel }}$ & Ho & H1 & Kesimpulan \\
\hline 0,824 & 4,823 & 2,201 & ditolak & diterima & Terdapat hubungan yang sangat erat \\
\hline
\end{tabular}

Sumber : Hasil Pengolahan Data, 2017 
Dari hasil perhitungan diperoleh koefisien korelasi kegunaan SAIBA dengan kualitas laporan keuangan sebesar 0,824. Nilai ini menunjukkan kekuatan hubungan dari variabel kegunaan SAIBA dengan kualitas laporan keuangan dapat digolongkan ke dalam tingkat hubungan sangat kuat yaitu berada pada interval $0,80-1,00$. Adapun arah hubungan hubungan kegunaan SAIBA dengan kualitas laporan keuangan adalah positif, artinya kegunaan SAIBA yang baik diikuti kualitas laporan keuangan yang baik dan sebaliknya.

$$
t=\frac{0,824 \sqrt{13-1-1}}{\sqrt{1-0,824^{2}}}=4,823
$$

Berdasarkan nilai yang disajikan pada tabel di atas dapat dilihat nilai t-hitung $(4,823)$ lebih besar dari $t_{\text {tabel }}(2,201)$. Jadi diperoleh keputusan pengujian Ho ditolak dan $\mathrm{H}_{1}$ diterima. Jadi hasil pengujian hipotesis menunjukkan bahwa dengan tingkat keyakinan 95\% hubungan kegunaan SAIBA dengan kualitas laporan keuangan signifikan (bermakna).

\section{Tabel 31.}

Hubungan Kemudahan Penggunaan SAIBA dengan kualitas laporan keuangan

\begin{tabular}{cccccc}
\hline $\mathbf{r}_{\mathbf{s}}$ & $\mathbf{t}_{\text {-hitumg }}$ & $\mathbf{t}_{\text {-tabel }}$ & $\mathbf{H o}$ & $\mathbf{H 1}$ & Kesimpulan \\
\hline 0,869 & 5,825 & 2,201 & ditolak & diterima & Terdapat hubungan yang sangat erat \\
\hline
\end{tabular}
Sumber : Hasil Pengolahan Data, 2017

Dari hasil perhitungan diperoleh koefisien korelasi Kemudahan Penggunaan SAIBA dengan kualitas laporan keuangan sebesar 0,869. Nilai ini menunjukkan kekuatan hubungan dari variabel Kemudahan Penggunaan SAIBA dengan kualitas laporan keuangan dapat digolongkan ke dalam tingkat hubungan sangat kuat yaitu 
ISSN: 2302-8556

E-Jurnal Akuntansi Universitas Udayana Vol.24.3.September (2018):1768-1798

berada pada interval 0,80-1,00. Adapun arah hubungan kemudahan penggunaan SAIBA dengan kualitas laporan keuangan adalah positif, artinya Kemudahan Penggunaan SAIBA yang baik diikuti kualitas laporan keuangan yang baik dan sebaliknya.

$$
t=\frac{0,869 \sqrt{13-1-1}}{\sqrt{1-0,869^{2}}}=5,825
$$

Berdasarkan nilai yang disajikan pada tabel di atas dapat dilihat nilai t-hitung $(5,825)$ lebih besar dari $t_{\text {-tabel }}(2,201)$. Jadi diperoleh keputusan pengujian Ho ditolak dan $\mathrm{H}_{1}$ diterima. Jadi hasil pengujian hipotesis menunjukkan bahwa dengan tingkat keyakinan 95\% hubungan Kemudahan Penggunaan SAIBA dengan kualitas laporan

Hasil pengujian hipotesis menunjukkan bahwa kekuatan hubungan dari variabel kegunaan SAIBA dengan kualitas laporan keuangan dapat digolongkan ke dalam tingkat hubungan sangat kuat. Hal ini didasarkan pada nilai koefisien korelasi dari hasil perhitungan sebesar 0,824 (berada pada interval $0,80-1,00$ ). Hasil penelitian ini mendukung hasil penelitian Najati, dkk (2017), Permana (2016), Permadi (2013), dan Bahar (2015), namun tidak sejalan dengan hasil penelitian Azwar, dkk (2016). Penelitian ini menunjukkan bahwa aplikasi SAIBA dapat membuat operator bekerja lebih cepat, dapat meningkatkan kinerja, meningkatkan produktivitas, efektivitas, sangat berguna, dan menjadikan pekerjaan menjadi lebih mudah.

Hasil pengujian hipotesis menunjukkan bahwa kekuatan hubungan dari variabel kemudahan penggunaan SAIBA dengan kualitas laporan keuangan dapat digolongkan ke dalam tingkat hubungan sangat kuat. Hal ini didasarkan pada nilai 
koefisien korelasi dari hasil perhitungan sebesar 0,869 (berada pada interval 0,801,00). Hasil penelitian ini mendukung hasil penelitian Najati (2017), Rahman dan Syafruddin (2017), Arih, dkk (2017), dan Bahar (2015), namun tidak sejalan dengan hasil penelitian Anggraini (2017) dan Azwar, dkk (2016). Penelitian ini menunjukkan bahwa aplikasi SAIBA mudah untuk dipelajari, mudah untuk dikontrol/dikendalikan, mudah dimengerti, fleksibel, mudah untuk jadi terampil, dan mudah digunakan.

\section{SIMPULAN}

Berdasarkan hasil pembahasan sebelumnya maka dapat ditarik simpulan bahwa kekuatan hubungan dari variabel kegunaan SAIBA dengan kualitas laporan keuangan dapat digolongkan ke dalam tingkat hubungan sangat kuat. Hal ini didasarkan pada nilai koefisien korelasi dari hasil perhitungan sebesar 0,824 (berada pada interval $0,80-1,00)$. Kekuatan hubungan dari variabel kemudahan penggunaan SAIBA dengan kualitas laporan keuangan dapat digolongkan ke dalam tingkat hubungan sangat kuat. Hal ini didasarkan pada nilai koefisien korelasi dari hasil perhitungan sebesar 0,869 (berada pada interval 0,80-1,00).

Berdasarkan kesimpulan yang telah disampaikan sebelumnya, maka saran yang dapat diberikan adalah Bagi Kantor Wilayah DJP Bali sebaiknya meningkatkan serta mempertahankan sistem yang sudah berjalan dengan baik seperti penggunaan Sistem Aplikasi Akuntansi Instansi Berbasis Akrual (SAIBA). Agar lebih memudahkan penggunaan dalam mengaplikasikan sistem tersebut. Kepada peneliti selanjutnya hendaknya menambahkan variabel lain yang memiliki hubungan dengan kualitas 
ISSN: 2302-8556

E-Jurnal Akuntansi Universitas Udayana Vol.24.3.September (2018):1768-1798

laporan keuangan serta menambah area sampelnya sehingga diperoleh hasil penelitian yang lebih baik lagi.

\section{REFERENSI}

Amriani, Tenry Nur. 2014. Menyongsong Penerapan Akuntansi Pemerintah Berbasis Akrual. $\quad$ http://www.bppk.kemenkeu.go.id/berita-makassar/19410 menyongsong-penerapan-akuntansi-pemerintahan-berbasis-akrual. Diakses 25 Mei 2017.

Anggraini, Novita. 2017. Analisa Keberhasilan Implementasi Sistem Akuntansi Instansi (SAI) Ditinjau dari Persepsi Individu Pengguna (Studi Empiris Pada Kementerian Perindustrian Republik Indonesia). Tesis Magister Sains Akuntansi pada Program Magister Ilmu Akuntansi Fakultas Ekonomi dan Bisnis Universitas Lampung, Bandar Lampung.

Arih, Tyas Ninditha., Sri Rahayu dan Annisa Nurbaiti. 2017. Analisa Faktor-Faktor yang Mempengaruhi Implementasi Standar Akuntansi "Pemerintahan" Berbasis Akrual pada Pemerintah Kota Bandung. Jurnal Manajemen Indonesia Vol. 17 No.1.

Azwar., Tenry Nur Amriani dan Achmat Subekan. 2016. Evaluasi Atas Implementasi Aplikasi Sistem Akuntansi Instansi Basis Akrual (SAIBA) Pada Mitra Kerja Kppn Gorontalo Dan Marisa. Jakarta : Badan Pendidikan dan Pelatihan Keuangan.

Bahar, Rafika Ewid. 2015. Implementasi Akuntansi Berbasis Akrual: Mampukah Meningkatkan Akuntabilitas dan Transparansi dalam Pelaporan Keuangan? Studi Kasus Pada Pemerintah Kota Semarang. Skripsi Sarjana Jurusan Akuntansi pada Fakultas Ekonomika dan Bisnis Universitas Diponegoro, Semarang.

Davis, Fred. D. 1986. A Technology Acceptance Model For Empirically Testing New End-User Information Systems: Theory And Results. Desertasi Massachusetts Institute Of Technology.

Deloitte Public Sector Paper. Mastering the Transformation: New Public Management, Accrual Accounting, and Budgeting (internet file, last updated November 2004).

Najati, Ida., Endar Pituringsih dan Animah. 2016. Implementasi Akuntansi Berbasis Akrual : Pengujian Determinan dan Implikasinya Terhadap Kualitas Laporan Keuangan Kementerian/Lembaga. Jurnal Akuntansi Universitas Jember Vol. 14 No. 1, Jember. 
Peraturan Menteri Keuangan No. 270/PMK.05/2014 tentang Penerapan Standar Akuntansi Pemerintahan Berbasis Akrual pada Pemerintah Pusat. 31 Desember 2014. Berita Negara RI Tahun 2014, No. 2071. Jakarta.

Peraturan Pemerintah No. 71 Tahun 2010 tentang Standar Akuntansi Pemerintahan. 22 Oktober 2010. Lembaran Negara RI Tahun 2010, No. 123. Jakarta.

Permadi, Angga Dwi. 2013. Pengaruh Penerapan Sistem Akuntansi Keuangan Pemerintah Daerah Terhadap Kualitas Laporan Keuangan Pemerintah Daerah (Studi Kasus pada Dinas Bina Marga Provinsi Jawa Barat). Skripsi Sarjana Ekonomi Program Studi Akuntansi pada Fakultas Ekonomi Universitas Widyatama, Bandung.

Permana, Arieffin Dian. 2016. Penerapan Aplikasi SAIBA Untuk Penyusunan Laporan Keuangan. Jurnal Akuntansi Universitas Jember Vol. 14 No. 1, Jember.

Rahman, Miftahur dan Muchamad Syafruddin. 2017. Faktor-Faktor yang Mempengaruhi Resistensi Pengguna dalam Implementasi Sistem Akuntansi Akrual. Diponegoro Journal of Accounting Vol. 6 No. 4 Halaman 1-9.

Sugiyono. 2010. Metodologi Penelitian Bisnis. Bandung: Alfabeta. . 2012. Metodologi Penelitian Bisnis. Bandung: Alfabeta. . 2013. Metodologi Penelitian Bisnis. Bandung: Alfabeta. . 2014. Metodologi Penelitian Bisnis. Bandung: Alfabeta. 